\title{
2014 Hot Topics
}

\section{血小板分野}

血小板分野は，今期も基礎・臨床いずれの領域に おいても注目すべき論文が報告されている.

\section{(1)造血幹細胞ニッチの巨核球}

造血幹細胞は骨髄にごく僅かにしか存在しないが (骨髄単核細胞中の約 $0.1 \%$ ), 自己複製能と全ての 血球細胞への分化能を有する細胞である。その機能 発現調節に重要な役割を有しているのがニッチと呼 ばれる微小環境である。造血幹細胞は特殊な微小環 境に存在していることが知られており，これまでは 非造血細胞である骨髄間質細胞のいくつかの種類が ニッチとして報告されていた。しかしながら，どの ようにして血液細胞からのフィードバックが造血幹 細胞に伝達されているかは不明であった。今回，造 血幹細胞からの分化産物である巨核球が骨髄内での 造血幹細胞ニッチとして機能していることを示す 3 本の論文が異なる研究グループから立て続けに報告 された ${ }^{1-3)}$ 、いずれの論文も骨髄内での造血幹細胞 と巨核球の局在を検討した結果，これら細胞が隣接 して存在していることを示している。そこで巨核球 を depletionした際の造血幹細胞の解析を行ってい る。いずれも急性に in vivoで巨核球を選択的に depletionしているが, Brunsらは, 造血幹細胞数の増加, Zhao らは，長期的に再構築能を有する long-term 造 血幹細胞の数は変わらず, short-term 造血幹細胞数 の増加, Nakamura-Ishizu らは, long-term 造血幹細胞 数の減少を示した。これらの機序として, Brunsら は CXCL4 (platelet factor 4 としても知られている), Zhao らは TGF-b1, Nakamura-Ishizu らはトロンボポ エチン (TPO)の関与を示した。報告による一致が認 められないが，いずれの報告も巨核球が造血幹細胞 由来のニッチ細胞として機能していることを示す新
血小板部門編集委員

松原由美子，大森 司，羽藤高明
規知見である。昨年，造血幹細胞集団の中に，TPO に制御される巨核球・血小板へ分化しやすい細胞集 団 (von Willebrand 因子発現造血幹細胞) が同定さ れ4，その細胞集団は，自己複製し，長期にわたり 骨髄細胞系譜へ偏りを示し、リンパ球に偏った造血 幹細胞を産生できる，すなわち，階層的血球分化モ デルに適合しない位置に存在していることが移植実 験により示されたが，この細胞集団と今回報告され た造血幹細胞のニッチとしての巨核球の関連が興味 深い.

\section{(2) 肝臓における TPO 産生調節機構}

TPO は巨核球分化・血小板産生の重要なサイト カインであることは，多くの知見の集積，そして $\mathrm{TPO}$ 受容体作動薬が血小板増多薬として臨床適応 されていることからも明らかである。TPOの主要 産生臓器は肝臓であり, 恒常的な発現を呈している ことが知られているが，その発現調節機構に関して は不明であった。今回，その調節機構の知見が報告 された が，その細胞老化に伴って脱シアル化血小板へと なっていく，脱シアル化血小板は肝臓の AshwellMorell 受容体に結合し，その結合を介したシグナル (JAK2-STAT3)によってTPO mRNA とたんぱく発現 が充進されることが in vivo と in vitro の検討によっ て報告されている。

（3）JPPP 試験：低容量アスピリンの連日内服 が動脈硬化リスクを有する日本人 (60 歳80 歳)の心血管イベントに影響を及ぼすか の検証

Japanese Primary Prevention Project(JPPP) 試験は, 
多施設，オープンラベル，無作為，パラレルグルー プの試験である ${ }^{6)}$. 14,464 人の 60 歳から 85 歳の患 者で高血圧，脂質異常，糖尿病を有する患者が 1007 施設から 2005 年から 2007 年の間に本試験に登録さ れた。患者は，アスピリン腸溶錠 $100 \mathrm{mg} /$ 日投与群 とアスピリン非投与群に $1: 1$ で無作為割り付けさ れた。フォローアップの期間は 6.5 年間, 2012 年の 5 月まで追跡された。アアトカムの評価は治療につ いて盲験にて遂行された。 Primary outcomeは複合 アウトカムで，心血管イベント (心筋梗塞・脳卒中 · 他の血管病変)の死亡と非致死的脳卒中 (脳梗塞 - 脳 出血・脳血管疾患等 $)+$ 非致死的心筋梗塞を複合し ている. Secondary outcomeはそれぞれのエンドポ イントを解析した。研究は, 中間解析におけるデー 夕モニタリング委員会から治療の無益性を指摘さ れ, 平均 follow up 5.02 年の時点で終了となった。 患者 14,464 人は, アスピリン投与群 7,220 人，アス ピリン非投与群 7,244 人であった。両群ともに 56 例 の致死的イベントが発症していた。非致死的脳卒中 はアスピリン投与群で 114 人，アスピリン非投与群 で 108 人, 非致死的心筋梗塞はアスピリン投与群で 20 人，アスピリン非投与群で 38 人だった。 5 年時 点の Primary outcomeは, アスピリン投与群， $2.77 \%$ （95\% CI：2.40-3.20），アスピリン非投与群 2.96\% （95\% CI：2.58-3.40）と両群で有意差を認めなかった $(\mathrm{p}=0.54)$. しかし，アスピリン投与群では非致死的 心筋梗塞を有意に減少させ $(\mathrm{p}=0.02)$ ， TIA に関して も有意に減少させた $(\mathrm{p}=0.04)$ 。 また, 出血に関して は，アスピリン投与群は，入院か輸血を必要とする 頭蓋外出血を有意に増加させた $(\mathrm{p}=0.004)$ 。結論と して, 低容量アスピリン連日投与は, 動脈硬化リス クのある日本人 60 歳-80 歳の心血管死亡 · 非致死 的脳卒中 · 非致死的心筋梗塞の複合アウトカムに影 響を与えなかった，と報告されている。本報告にお いても層別化解析では有意差を示していることか ら, 今後の層別化など解析結果が興味深い.

\section{(4) 薬剤溶出性ステント留置後の抗血小板薬 2 剂併用療法期間の 12 カ月と 30 カ月との 比較}

冠動脈ステント留置後は血栓症予防のために抗血 小板薬の 2 剤(アスピリンとチエノピリジン系薬剤
[クロピドグレルあるいはプラスグレル］)併用療法 が行われているが，この 2 剂併用療法を長期にわた り行った場合のリスク・ベネフィットは明らかにさ れていなかった。今回, 冠動脈ステント留置術にて 薬剤溶出性ステントを留置された患者を対象にチエ ノピリジン系薬剤(クロピドグレルあるいはプラス グレル)とアスピリンによる治療を 12 カ月間行った 後, 患者をさらに 18 カ月間チエノピリジン投与を 継続する群とプラセボ群に無作為に割り付けた7). アスピリンは全例で継続投与である。評価項目は, 12 力月目から 30 力月目までの期間におけるステン 卜血检症と主要な心血管・脳血管有害事象 (死亡, 心筋梗塞，脳卒中の複合) とされた。また，安全性 の評価として，中程度または重度の出血とした。対 象患者 9,961 人をチエノピリジン継続群とプラセボ 群に無作為に割り付けた。千エノピリジン継続群で は, プラセボ群と比較して, ステント血栓症の発生 率 $(0.4 \%$ 対 $1.4 \%, \mathrm{P}<0.001)$ と, 主要な心血管・脳 血管有害事象の発現率 $(4.3 \%$ 対 $5.9 \%, \mathrm{P}<0.001)$ が 減少した。心筋梗塞の発生率は，千エノピリジン継 続群のほうがプラセボ群よりも低かった $(2.1 \%$ 対 $4.1 \%, \mathrm{P}<0.001)$. 全死因死亡率は, チエノピリジン 継続群 $2.0 \%$ ，プラセボ群 $1.5 \%$ であった $(\mathrm{P}=0.05)$. 中等度または重度の出血の発生率は, チエノピリ ジンの継続投与によって上昇した(2.5\%対 $1.6 \%$, $\mathrm{P}=0.001$ ). 両群とも, チエノピリジン投与中止後の 3 力月間にステント血栓症と心筋梗塞のリスク上昇 が認められた。結論として, 薬剤溶出性ステント留 置後に抗血小板薬 2 郕併用療法を 1 年以上行うと, アスピリン療法単独の場合と比較して，ステント血 栓症および主要な心血管・脳血管有害事象のリスク が有意に低下したが，出血のリスクの上昇との関連 が認められた。この2 剂併用療法の有用性(有効性 と安静性のバランス)に関しては, 最近のメタアナ リシスによっても 1 年以上投与の場合の出血リスク を示している8

\section{(5) CalDAG-GEFI 遺伝子変異は血小板機能異 常・重篤な出血症状を起こす}

CalDAG-GEPI は，血小板機能発現に重要な膜受 容体 (glycoprotein IIbIIIa や P2Y12 など)の血小板活 性化シグナル伝達に働くことが知られている。今 
回，重篤な出血症状を呈する 3 兄弟に関して，全ゲ ノム解析を行ったところ CalDAG-GEFI 遺伝子が変 異していることを見いだしだ9)。この遺伝子変異を
細胞に発現させた結果，患者血小板の表現型を支持 すべくRac-1 GTP 結合減少を示した.

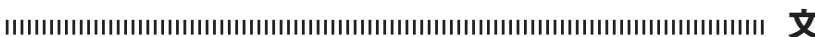

1) Bruns I, Lucas D, Pinho S, Ahmed J, Lambert MP, Kunisaki Y, Scheiermann C, chiff L, Poncz M, Bergman A, Frenette PS: Megakaryocytes regulate hematopoietic stem cell quiescence through CXCL4 secretion. Nat Med 20: 1315-1320, 2014.

2) Zhao M, Perry JM, Marshall H, Venkatraman A, Qian $P, \mathrm{He}$ XC, Ahamed J, Li L: Megakaryocytes maintain homeostatic quiescence and promote post-injury regeneration of hematopoietic stem cells. Nat Med 20: 1321-1326, 2014.

3) Nakamura-Ishizu A, Takubo K, Fujioka M, Suda T: Megakaryocytes are essential for HSC quiescence through the production of thrombopoietin. Biochem Biophys Res Commun 454: 353-357, 2014.

4) Sanjuan-Pla A, Macaulay IC, Jensen CT, Woll PS, Luis TC, Mead A, Moore S, Carella C, Matsuoka S, Bouriez Jones T, Chowdhury O, Stenson L, Lutteropp M, Green JC, Facchini R, Boukarabila H, Grover A, Gambardella A, Thongjuea S, Carrelha J, Tarrant P, Atkinson D, Clark SA, Nerlov C, Jacobsen SE: Platelet-biased stem cells reside at the apex of the haematopoietic stem-cell hierarchy. Nature 502: 232-236, 2013.

5) Grozovsky R, Begonja AJ, Liu K, Visner G, Hartwig JH, Falet H, Hoffmeister KM: The Ashwell-Morell receptor regulates hepatic thrombopoietin production via JAK2-STAT3 signaling. Nat Med 21: 47-54, 2015.
献

6) Ikeda $Y$, Shimada K, Teramoto $T$, Uchiyama S, Yamazaki T, Oikawa S, Sugawara M, Ando K, Murata M, Yokoyama K, Ishizuka N: Low-dose aspirin for primary prevention of cardiovascular events in Japanese patients 60 years or older with atherosclerotic risk factors: a randomized clinical trial. JAMA 312: 2510-2520, 2014.

7) Mauri L, Kereiakes DJ, Yeh RW, Driscoll-Shempp P, Cutlip DE, Steg PG, Normand SL, Braunwald E, Wiviott SD, Cohen DJ, Holmes DR Jr, Krucoff MW, Hermiller J, Dauerman HL, Simon DI, Kandzari DE, Garratt KN, Lee DP, Pow TK, Ver Lee P, Rinaldi MJ, Massaro JM; DAPT Study Investigators: Twelve or 30 months of dual antiplatelet therapy after drugeluting stents. N Engl J Med 371: 2155-2166, 2014.

8) Stefanini GG, Siontis GC, Cao D, Heg D, Jüni P, Windecker S: Short versus long duration of DAPT after DES implantation: a meta-analysis. J Am Coll Cardiol 64: 953-954, 2014.

9) Canault M, Ghalloussi D, Grosdidier C, Guinier M, Perret C, Chelghoum N, Germain M, Raslova H, Peiretti F, Morange PE, Saut N, Pillois X, Nurden AT, Cambien F, Pierres A, van den Berg TK, Kuijpers TW, Alessi MC, Tregouet DA: Human CalDAG-GEFI gene (RASGRP2) mutation affects platelet function and causes severe bleeding. J Exp Med 211: 13491362, 2014. 


\section{Hot Topics}

\section{凝固分野}

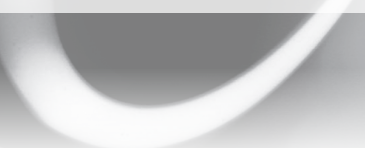

2014 年の凝固分野のホットトピックスを, とく に血友病, 凝固因子, 新規経口抗凝固薬について述 べる.

(1)血友病 B 患者への AAV8 ベクターを用いた遺伝 子治療において，低，中，および高用量べクターを 用いた各 2 名 (計 6 名)ずつの臨床治験での 16 カ月 間の治療成績がすでに報告され，今回，同 6 名とさ らに高用量治療べクター群の 4 名の計 10 名のさら なる長期安全性と有効性について報告された 床第 I 相の Dose-escalation study からの 6 名は 3 年 以上で FIX:C 1-6\%が持続発現しており, なかでも 高用量 6 名については FIX:C 5.1 $1.7 \%$ が持続発現 していた。 そして出血頻度も $90 \%$ 以上の減少を認 めた。副作用は一過性の肝機能異常を呈したが，プ レドニゾロンで回復した。血友病 B 患者に対する AAV8 ベクター単回投与では長期間の FIX 発現とそ れに伴う臨床症状の改善を示し, 遅発型中毒性は認 められなかった。このことは近い将来, 遺伝子治療 による血友病 B 克服につながることを大きく期待 させる。

(2)血友病の止血治療として, ここ $2-3$ 年は幾つかの 長時間作用型凝固因子製剂の臨床試験が行われてお り，その有効性と安全性が報告されてきた2,3)。新 生児型 $\mathrm{Fc}$ 受容体 $(\mathrm{FcRn})$ の性質を利用した融合蛋白 や，ポリエチレングリコール(PEG)の付加などが, 因子半減期を長くさせる作用を有する。これら製剤 は，血友病患者の今後の止血治療の柱になっていく ものと期待される。ささらに，作用増強型の製剤への 基礎研究が多くなされており, 次の 2 つの報告は増 強機序に多いに興味をひくものである. FVIII A2 ド
凝固部門編集委員

中村真潮，長尾毅彦，野上恵嗣
メインは活性発現に必須領域であるが, A2 ドメイン 内 D519/E665をそれぞれ valineに置換させて，非共 有結合により安定化させることでトロンビン生成能 を約 5 倍上昇させ，さらに本変異 FVIII 投与により 血友病 A マウスの血管内フィブリン沈着を 4 倍以 上増強させ, 出血時に対する止血能も2 倍増加させ た4)。一方 FVに执いて，A2-A3 ドメインを disulfide 結合し,ささに APC 開裂部位 $(R 306 / 506 / 679 \mathrm{Gln})$ を変異させた super-FVa が in vitro での凝固能克進を もたらすこと, さらに血友病 A マウスに対する止 血効果の増強をin vivo で示すことが報告された 今後, 新規機序による作用増強型や長時間作用型の 基礎研究がさらに行われていくことが期待される。

(3)インヒビター保有血友病の止血治療で遺伝子組換 えFVIIaのバイパス製剤が用いられるが，その止血 機序は不明であった。生理的には FVIIaは組織因子 (TF) 依存性に作用増強を示すが, rFVIIaの止血機 序は TF 非依存性で発動することがが，2グループ の報告で明らかになった か, $^{6,7}$. 一方，昨年トピック スで紹介したACE910は，抗体の 2 つの抗原結合部 位に FIXa と FXが結合する bispecific 抗体で, FVIII と同様の機能を発揮する。 ACE910は, FVIII イン ヒビター存在下で凝固機能を促進し, 出血時のカニ クイザルへの投与でも止血作用を示し, 半減期 3 週 間と持続性も高かった。今回さらに, ACE910は後 天性血友病 A モデルのカニクイザルでの長期間の 関節出血も完全に予防しうることが報告された ${ }^{8)}$. 現在, 国内臨床第 I 相試験中であり, インヒビター 有無に関わらず週 1 回皮下注射で出血予防効果を示 し, 血友病 Aの新規治療コンセプトとして多いに 期待されている. 
(4)血友病の遺伝子治療では, Matsui らは ${ }^{9)}$, fulllength FVIII cDNA を非ウイルスベクターである piggyBac transposon ベクターを用いて，ヒト 293T 細胞 やiPS 細胞に導入し FVIII を in vitroで発現したこと， そして免疫抑制を加えた血友病 A マウスに piggyBac transposonベクターを投与し，インヒビターが出現 することなく，300 日以上の間 FVIII を安定して発 現したことを報告した． Lillicrapのグループも ${ }^{10)}$, ex vivo での遺伝子治療として, レンチウイルスで 導入させた自己 FVIII 発現 BOECs (blood outgrowth endothelial cell) を大網に移植し，FVIII 抗原 $>40 \%$ が 1 年以上発現したことが報告され，また Montgomery らのグループは ${ }^{11)}$, 血小板-FVIII (2bF8) 遺伝子改変 ヒト臍带血幹細胞移植にて血友病 A マウスの止血機 能を改善した報告が以前なされていたが, 今回, レン チウイルスベクターを用いて血小板-FVIII $(2 \mathrm{bF} 8)$ 遺 伝子をヒ卜臍帯血幹細胞に導入させ，ヒト血小板上 にFVIII を発現させることが適していることを，凝 血学的評価から明らかにした。血友病 Aにおいて 種々の遺伝子治療の試みが相次いで報告されてお り，今後の展開に期待される.

(5) FVIII の産生部位の特定が進められ，今年になっ て FVIII の主要産生部位は, 血管内皮細胞であるこ と，その中でもとくに肝類洞内皮細胞 (liver sinusoidal endothelial cells: LSECs)が重要であることが明ら
かになった ${ }^{12,13)}$ 。また, FVIII の von Willebrand factor (VWF) との主要な結合部位はVWF-D'ドメイン に存在すること，そしてVWF-D'ドメインに存在 する trypsin-inhibitor-like (TIL') 領域の構造がとくに FVIII との結合に重要であることが明らかにされた。 さらに，FVIII 安定化のためにはVWF-D'D3 ドメ イン全体が必要であることも示された ${ }^{14,15)}$.この柔 軟な VWF-D'ドメインの立体構造は，VWFにおけ る FVIII 結合という重要な機能を理解する上で重要 な一歩であると考えられ，今後のさらなる解明に注 目したい.

(6)新規経口抗凝固薬の大規模臨床試験は, 2013 年 でほぼ全てが出そろった。2014 年には日本人を含 む東アジア人での解析も報告され ${ }^{16)}$ ，白人と比較す ると脳出血の頻度が新規経口抗凝固薬では変わらな いが，ワルファリンでは明らかに高いことが明らか となっている。そして2014年 9 月には, 経口Xa 阻害薬としてはわが国では初めて，静脈血栓塞栓症 の治療ならびに二次予防に対してエドキサバンが適 応を取得した。ワルファリンに代わる経口抗凝固薬 として非常に期待されており, さらに現在開発中の 経口 Xa 阻害薬も間もなく臨床使用される可能性が 高い。実臨床での有用性の情報は未だ不足している が, 今後の臨床データの集積を待ちたい.

献 |||||||||||||||||||||||||||||||||||||||||||||||||||||||||||||||||||||||||||||||||||||||||||||||||||||||

S, Neelakantan S, Cristiano LM, Goyal J, Sommer JM, Dumont JA, Dodd N, Nugent K, Vigliani G, Luk A, Brennan A, Pierce GF; A-LONG Investigators: Phase 3 study of recombinant factor VIII Fc fusion protein in severe hemophilia A. Blood 123: 317-325, 2014.

4) Leong L, Sim D, Patel C, Tran K, Liu P, Ho E, Thompson T, Kretschmer PJ, Wakabayashi H, Fay PJ, Murphy JE: Noncovalent stabilization of the factor VIII A2 domain enhances efficacy in hemophilia A mouse vascular injury models. Blood 125: 392-398, 2015.

5) von Drygalski A, Cramer TJ, Bhat V, Griffin JH, Gale AJ, Mosnier LO: Improved hemostasis in hemophilia mice by means of an engineered factor Va mutant. J Thromb Haemost 12: 363-372, 2014.

6) Feng D, Whinna H, Monroe D, Stafford DW: FVIIa as used pharmacologically is not TF dependent in hemophilia $\mathrm{B}$ mice. Blood 123: 1764-1766, 2014. 
7) Augustsson C, Persson E: In vitro evidence of a tissue factorindependent mode of action of recombinant factor VIIa in hemophilia. Blood 124: 3172-3174, 2014.

8) Muto A, Yoshihashi K, Takeda M, Kitazawa T, Soeda T, Igawa T, Sampei Z, Kuramochi T, Sakamoto A, Haraya K, Adachi K, Kawabe Y, Nogami K, Shima M, Hattori K: Anti-factor IXa/ $\mathrm{X}$ bispecific antibody ACE910 prevents joint bleeds in a longterm primate model of acquired hemophilia A. Blood 124: 3165-3171, 2014.

9) Matsui H, Fujimoto N, Sasakawa N, Ohinata Y, Shima M, Yamanaka S, Sugimoto M, Hotta A: Delivery of full-length factor VIII using a piggyBac transposon vector to correct a mouse model of hemophilia A. PLoS ONE 9: e104957, 2014.

10) Ozelo MC, Vidal B, Brown C, Notley C, Hegadorn C, Webster S, Harpell L, Ahlin J, Winterborn A, Handforth J, Arruda VR, Hough C, Lillicrap D: Omental implantation of BOECs in hemophilia dogs results in circulating FVIII antigen and a complex immune response. Blood 123: 4045-4053, 2014.

11) Shi Q, Kuether EL, Chen Y, Schroeder JA, Fahs SA, Montgomery RR: Platelet gene therapy corrects the hemophilic phenotype in immunocompromised hemophilia A mice transplanted with genetically manipulated human cord blood stem cells. Blood 123: 395-403, 2014.

12) Everett LA, Cleuren AC, Khoriaty RN, Ginsburg D: Murine coagulation factor VIII is synthesized in endothelial cells. Blood 123: 3697-3705, 2014.

13) Fahs SA, Hille MT, Shi Q, Weiler H, Montgomery RR: A conditional knockout mouse model reveals endothelial cells as the principal and possibly exclusive source of plasma factor VIII. Blood 123: 3706-3713, 2014.

14) Shiltagh N, Kirkpatrick J, Cabrita LD, McKinnon TA, Thalassinos K, Tuddenham EG, Hansen DF: Solution structure of the major factor VIII binding region on von Willebrand factor. Blood 123: 4143-4151, 2014.

15) Yee A, Gildersleeve RD, Gu S, Kretz CA, McGee BM, Carr KM, Pipe SW, Ginsburg D: A von Willebrand factor fragment containing the $\mathrm{D}^{\prime} \mathrm{D} 3$ domains is sufficient to stabilize coagulation factor VIII in mice. Blood 124: 445-452, 2014.

16) Nakamura $M$, Wang $Y Q$, Wang $C$, Nakamura $M$, Wang $Y Q$, Wang C, Oh D, Yin WH, Segers A, Büller H. Treatment of Venous Thromboembolism in East Asian (including Japanese) Patients - A Hokusai-VTE Subanalysis. 2013 The 78th Annual Scientific Meeting of the Japanese Circulation Society, 21th March, 2014. 


\section{Hot Topics}

\section{線溶分野}

線溶部門編集委員

鈴木優子, 森下英理子, 永井信夫

【臨床領域】近年わが国で肺血栓塞栓症は増加傾向に あるが，その急性期の血栓溶解療法に関して N Engl J Med に報告された (Pulmonary Embolism Thrombolysis; PEITHO trial $)^{1)}$. 早期死亡の高リスク群では禁忌 例を除いて積極的な血栓溶解療法が推奨されるが, 中リスク群における同療法に関しては一定の見解が 得られていない. 正常血圧で右心機能不全・心筋傷 害を認める中リスク群の急性肺塞栓症例に対し, へ パリンによる抗凝固療法のみの群とそれに加えて血 栓溶解薬 $[$ 遺伝子組み換え組織プラスミノゲンアク チベータ (rt-PA)：tenecteplase]を投与(体重に応じて 30-50 mg, 単回ボーラス) した群とにおいて, その有 効性が検討された，rt-PA 投与の有無にて死亡リス クは変わらなかったものの rt-PA 投与群では血行動 態不良に陥るリスクは軽減された。しかし当然のこ とながら出血リスクは増大し，とくに 75 歳以上で 顕著であったことから, ベネフィット・リスク評価 に基づいた症例選択の重要性が改めて認識された。

【創薬】東京農工大学の蓮見らにより, 糸状菌産生小 分子化合物である Stachybotrys microspora triprenyl phenol (SMTP) 同族体の一つ, SMTP-7 がプラスミノ ゲン $(\mathrm{Plg})$ の立体構造を変えて Plgアクチベータ （PA）による活性化を促進するという Plg モジュレー ター活性を有し，サルの中大脳動脈閉塞による脳梗 塞モデルにて優れた治療効果を示すこと²), rt-PAに 比し出血合併症が軽減されること光が報告された。 既にコード名 TMS-007 として臨床第 I 相試験が開 始されている(2014 年 11 月現在, 全6コホートの 第 1 コホートが完了). SMTP-7 は血检溶解作用の みならず神経保護作用や抗炎症作用を有することも 示され4)，その臨床応用が期待される。

【基礎領域】脳血管障害と線溶に関して, とくに $\mathrm{tPA}$
による血栓溶解時の blood-brain barrier(BBB) 傷害に ついて総説がまとめられた ${ }^{5)}$. 内因性 tPA あるいは 投与されたrt-PAによる BBBの破壊には low-density lipoprotein receptor (LDLR) -related protein (LRP) など を介した matrix metalloproteinase(MMPs)による作用 が主であるとするプラスミン (Plm) 非依存性の機構 に対し，PlmによるMMPsの活性化あるいは BBB 基質の分解，プロテアーゼ活性化受容体を介したシ グナリング形成などへ果たす役割を再認識する必要 性が示された。有効な脳梗塞治療は現在なお模索中 で，その一つとして $\alpha 2$-antiplasmin ( $\alpha 2 \mathrm{AP})$ 活性の阻 害により脳梗塞後の傷害を低減できる可能性が示さ れだ

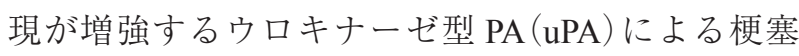
周辺部位の神経機能回復促進の可能性も新たに示唆 された7).

tPAの新規作用として, 骨修復過程における tPA/ $\mathrm{Plg}$ 系の関与を近畿大学の河尾らのグループが報告 した ${ }^{8)}$. tPA 欠損 $\left(t P A^{-/-}\right)$マウスでは骨欠損モデルに おいて骨芽細胞の増殖による骨形成促進作用が野生 型に比し遅延することが初めて明らかにされた。 tPA の作用はアネキシン A2 を介すること, 細胞内 シグナリング分子として ERK $1 / 2$ のリン酸化, 血管 内皮細胞増殖因子 (VEGF) や低酸素誘導因子 (HIF-1) の発現増強を介することが示された。ささらに同グ ループから糖尿病モデルでの骨欠損修復遅延に対す る線溶系の関与 ${ }^{9)}$ も示され, 生理的範囲で繰り返さ れる骨のリモデリングにおける骨芽細胞機能への線 溶系の関与，あるいは老人性低代謝回転型骨粗鬆症 における骨形成能低下に対する PAI-1の関与の可能 性など興味深い。また炎症反応とのクロストークの 観点から，虚血再還流モデルにおいて，tPA は再還 
流初期相において酵素活性依存性に好中球浸潤を促 進するとともに, 酵素活性非依存性に組織内の肥満 細胞の活性化や血管透過性の元進を介して再還流血 管内への好中球接着をさらに促進することが示され た ${ }^{10)}$. 虚血再還流傷害では, 虚血組織へ浸潤した白 血球から放出される前炎症性サイトカインや活性酸 素種，プロテアーゼなどにより組織傷害が促進され る一方で, 浸潤白血球は抗炎症性因子の放出や残骸 物の食作用を介して再生, 治癒を促進することか ら, 炎症惹起あるいは治癒過程の時相と線溶系との 解明にはさらに詳細な検討が必要であろう。

PAI-1 も線溶阻害因子としての作用以外にも種々 の現象に関与することがこれまでにも多く報告され ているが, 老化, 血管新生・細胞遊走・腫瘍増殖転 移との関連性における進展を紹介する。 PAI-1 は, 老化細胞から分泌される物質に含まれるばかりでな く，老化シグナルを誘導する p53(癌抑制遺伝子)の 下流標的因子の一つとしても機能しており, PAI-1 の発現抑制によりPI (3)K-PKB-GSK3 $\beta$ 経路が活性 化されてサイクリン D1が核内に保持される機序が, これまでに示されていた，個体レベルでは，ヒト早 発性老化症候群モデルである Klotho 欠損 $(k l / k l)$ マウ スにおいて, PAI-1も同時に欠損させる $\left(\mathrm{kl} / \mathrm{klpai-1^{-/- } )}\right.$ と老化が遅延し寿命が延長することが新たに報告さ れた ${ }^{11)} . k l / k l$ マウスでは, 発生や分化増殖に関与す るWnt，IGF-1，TGF- $\beta$ などのシグナル伝達が抑制 され，抗老化として作用する Klotho 機能が欠損す る。そのため寿命は 8-12 週と短命となり, 腎硬化 症, 動脈硬化症, 肺気腫, 骨粗鬆症などをきたすと される.今回の報告により, PAI-1が老化のマーカー としてあるいは細胞老化を促進させる役割を有する だけでなく，個体の老化にも関与している可能性が 明らかとなった。ヒトに打ける血管老化の観点から PAI-1 がどのように動脈硬化などの病態に関連する のかも含め興味深いところである。

PAI-1 は血管新生に対して proangiogenic 作用, antiangiogenic 作用ともに有するとされる。前者は タンパク分解抑制による細胞外マトリックスの安定 が関わり, 後者は細胞表面の $\alpha_{v} \beta_{3}$ インテグリン $\left(\alpha_{v} \beta_{3}\right)$ と結合し細胞の接着や遊走に関わるビトロネ クチン $(\mathrm{Vn}) や, \mathrm{uPA}$ 受容体 (uPAR)に対する PAI-1の 結合が関与する。 Vn 結合 $\alpha_{v} \beta_{3}$ は, VEGF 受容体-2
(VEGFR-2) と結合してVEGFによる血管新生シグ ナリングを増強することから，Wuらは PAI-1によ るVEGF シグナリング修飾の可能性を初めて示唆 した ${ }^{12)}$. PAI-1 はVn と結合してあるいは uPA/uPAR と結合しさらに超低密度リポタンパク受容体と複合 体を形成して， $\alpha_{v} \beta_{3}$ とVEGFR-2 との結合を阻害し, VEGFR-2 のリン酸化に始まるシグナリングカス ケードを減弱させる結果, 細胞接着や遊走能, 微小 血管形成能が抑制されることが示された。また, Bajou らは新規経路として PAI-1 が prolactin (PRL) のアミノ末端ペプチドとして知られる 16K PRLに よる antiangiogenic 作用, profibrinolytic 作用を仲介 することを Nature Medicine 誌に報告した ${ }^{13)}$ １6 PRL とは PRL がカテプシン D P MMP により分解 されて生ずるもので, 糖尿病性網膜症では減少しま た血管内皮細胞は $16 \mathrm{~K}$ PRL に対し高い親和性を有 する．実際に 16K PRL が PAI-1 の reactive center loop の近傍に結合すること, この結合は比較的高い $K_{\mathrm{d}}$ $(1.1 \mu \mathrm{M})$ を示すが PAI-1/uPA/uPAR/LRP からなる複 合体形成 PAI-1 に対してはより高い親和性で結合す る可能性が示され, $16 \mathrm{~K}$ PRL 発現系で認められる 血管新生, 細胞遊走や腫瘍増殖の抑制作用, さらに 血栓溶解促進作用はいずれも $16 \mathrm{~K}$ PRL 結合による PAI-1 作用 (proangiogenic, antifibrinolytic 作用)の阻 害に依存することが明らかにされた，前述の論文と は相反する結論であり, PAI-1 濃度や時相を含めた 実験モデルの差異を熟慮することが必要である.

腫瘍の分野では, がん細胞脳転移巣形成と成長に おける PA 抑制活性を有する serine protease inhibitors (serpins)の役割が明らかにされた ${ }^{14)}$. 一般的に BBB を超えて浸潤した腫瘍細胞の多くは生着できず消滅 する。これはアストロサイトからのPAにより生成 された Plmによる二つの作用による，(1)アストロ サイト膜表面の Fas リガンドを遊離させ, それが腫 瘍細胞に作用しアポトーシスを誘導させる。(2)腫瘍 細胞が発現し毛細血管壁に沿った播種に関わる神経 接着因子 L1CAM を分解する。肺がんや乳がんの脳 転移細胞では, ニューロセルピンや serpin B2 に代 表される serpinを高発現しており, PA 活性を阻害 することで上記の Plm 作用を減弱させるため, がん 細胞の生着と血管系を巻き込んだ転移巣の形成が促 進されることが初めて明らかにされた。 
1) Meyer G, Vicaut E, Danays T, Agnelli G, Becattini C, BeyerWestendorf J, Bluhmki E, Bouvaist H, Brenner B, Couturaud F, Dellas C, Empen K, Franca A, Galiè N, Geibel A, Goldhaber SZ, Jimenez D, Kozak M, Kupatt C, Kucher N, Lang IM, Lankeit M, Meneveau N, Pacouret G, Palazzini M, Petris A, Pruszczyk P, Rugolotto M, Salvi A, Schellong S, Sebbane M, Sobkowicz B, Stefanovic BS, Thiele H, Torbicki A, Verschuren F, Konstantinides SV; PEITHO Investigators: Fibrinolysis for patients with intermediate-risk pulmonary embolism. N Engl J Med 370: 1402-1411, 2014.

2) Sawada H, Nishimura N, Suzuki E, Zhuang J, Hasegawa K, Takamatsu H, Honda K, Hasumi K: SMTP-7, a novel smallmolecule thrombolytic for ischemic stroke: a study in rodents and primates. J Cereb Blood Flow Metab 34: 235-241, 2014.

3) Ito A, Niizuma K, Shimizu H, Fujimura M, Hasumi K, Tominaga T: SMTP-7, a new thrombolytic agent, decreases hemorrhagic transformation after transient middle cerebral artery occlusion under warfarin anticoagulation in mice. Brain Res 1578: 38-48, 2014.

4) Matsumoto N, Suzuki E, Ishikawa M, Shirafuji T, Hasumi K: Soluble Epoxide Hydrolase as an Anti-inflammatory Target of the Thrombolytic Stroke Drug SMTP-7. J Biol Chem. [Epub ahead of print] 2014.

5) Niego B, Medcalf RL: Plasmin-dependent modulation of the blood-brain barrier: a major consideration during tPA-induced thrombolysis? J Cereb Blood Flow Metab 34: 1283-1296, 2014.

6) Reed GL, Houng AK, Wang D: Microvascular Thrombosis, Fibrinolysis, Ischemic Injury, and Death After Cerebral Thromboembolism Are Affected by Levels of Circulating $\alpha 2-$ Antiplasmin. Arterioscler Thromb Vasc Biol 34: 2586-2593, 2014.

7) Wu F, Catano M, Echeverry R, Torre E, Haile WB, An J, Chen C, Cheng L, Nicholson A, Tong FC, Park J, Yepes M: Urokinase-type plasminogen activator promotes dendritic spine recovery and improves neurological outcome following ischemic stroke. J Neurosci 34: 14219-14232, 2014.
8) Kawao N, Tamura Y, Okumoto K, Yano M, Okada K, Matsuo $\mathrm{O}$, Kaji H: Tissue-type plasminogen activator deficiency delays bone repair: roles of osteoblastic proliferation and vascular endothelial growth factor. Am J Physiol Endocrinol Metab 307: E278-288, 2014.

9) Mao L, Kawao N, Tamura Y, Okumoto K, Okada K, Yano M, Matsuo O, Kaji H: Plasminogen activator inhibitor-1 is involved in impaired bone repair associated with diabetes in female mice. PLoS ONE 9: e92686, 2014.

10) Uhl B, Zuchtriegel G, Puhr-Westerheide D, Praetner M, Rehberg M, Fabritius M, Hessenauer M, Holzer M, Khandoga A, Fürst R, Zahler S, Krombach F, Reichel CA: Tissue plasminogen activator promotes postischemic neutrophil recruitment via its proteolytic and nonproteolytic properties. Arterioscler Thromb Vasc Biol 34: 1495-1504, 2014.

11) Eren M, Boe AE, Murphy SB, Place AT, Nagpal V, MoralesNebreda L, Urich D, Quaggin SE, Budinger GR, Mutlu GM, Miyata T, Vaughan DE: PAI-1-regulated extracellular proteolysis governs senescence and survival in Klotho mice. Proc Natl Acad Sci USA 111: 7090-7095, 2014.

12) Wu J, Strawn TL, Luo M, Wang L, Li R, Ren M, Xia J, Zhang Z, Ma W, Luo T, Lawrence DA, Fay WP: Plasminogen Activator Inhibitor-1 Inhibits Angiogenic Signaling by Uncoupling Vascular Endothelial Growth Factor Receptor-2- $\alpha$ V $\beta 3$ Integrin Cross Talk. Arterioscler Thromb Vasc Biol. [Epub ahead of print] 2014.

13) Bajou K, Herkenne S, Thijssen VL, D’Amico S, Nguyen NQ, Bouché A, Tabruyn S, Srahna M, Carabin JY, Nivelles O, Paques C, Cornelissen I, Lion M, Noel A, Gils A, Vinckier S, Declerck PJ, Griffioen AW, Dewerchin M, Martial JA, Carmeliet P, Struman I: PAI-1 mediates the antiangiogenic and profibrinolytic effects of $16 \mathrm{~K}$ prolactin. Nat Med 20: 741-747, 2014.

14) Valiente M, Obenauf AC, Jin $X$, Chen $Q$, Zhang XH, Lee DJ, Chaft JE, Kris MG, Huse JT, Brogi E, Massagué J: Serpins promote cancer cell survival and vascular co-option in brain metastasis. Cell 156: 1002-1016, 2014. 


\section{Hot Topics}

\section{血管分野}

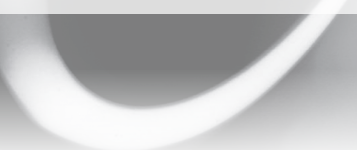

血管分野でも新たな技術革新や視点が生まれてい ます。本学会誌では, 代謝研究 (2014 年 3 号), 細胞 間クロストーク (2014 年 5 号) などの興味深い特集が くまれました。また昨年大阪大会での学術推進委員 会シンポジウムでは「血管の発生および構成を制御 する血球系細胞のダイナミックス」と題して血管新 生における骨髄細胞の役割や血管成熟やリモデリン グの機序など発展性のある発表がなされました。本 稿では最新技術, 新たな視点, 血管内皮の新機能, 臨床研究から重要で興味深い論文を紹介します。

\section{1，最新技術}

\section{(1)人工脾臟}

敗血症治療に期待がかかる微生物除去システムが 開発された. Kang (1) $^{1)}$ 脾臓血管と血流からヒント をえて, 血液中から効果的に病原体や毒素を除去で きる体外システムを開発した。あらゆる病原体を捕 獲できるように，マンノース結合レクチン(補体や 血液凝固系を活性化しないように改変済)を磁性 ビーズに結合させた。体外循環病原体除去システム は, 磁性ビーズと血液のインキュベーター部分, 脾 臓の微小血管の血流動態を模した還流部からなり, 微生物を捕獲した磁性ビーズを還流部の磁石で吸着 させる，著者らはこの人工脾蔵に細菌と真菌を混ぜ たヒト血液 $5 \mathrm{~L}$ を毎時 $1 \mathrm{~L}$ の速度で還流させ病原体 の大部分を除去することに成功した。 またラット血 液の黄色ブドウ球菌量や大腸菌量が $90 \%$ 以上減少 し, 組織内炎症細胞浸潤や血液の炎症性サイトカ インも抑制された。さらにエンドトキシンショック モデルのラットの致死率を劇的に改善させた。吸着 されなかった磁性ビーズが体内に入るという懸念は あるものの, 病原体が不明のままでも使用でき, 敗
血管部門編集委員

山下 篤, 竹下享典, 小亀浩市
血症治療に劇的な進歩が期待される.

\section{(2)革新的 3 次元解析技術}

組織の透過技術と 3 次元染色技術が急速に進歩し ている. Susaki $ら^{2)}$ は, 固定後のマウス脳組織を透 明化する試薬，屈折率を均一化する試薬，そして 3 次元画像を処理する方法を開発し, CUBIC (clear, unobstructed brain imaging cocktails and computational analysis）と名付けた。この処理により，様々な蛍光 試薬や蛍光蛋白でマウスの脳全体の可視化, 抗体に よる 3 次元染色, 単一軸索突起やシナプス小胞蛋白 の観察が可能であった。ささらに，核染色から得られ る画像との統合により位置情報の取得や個体間の比 較を可能にする解析技術を確立した。一方 Yang ら ${ }^{3)}$ は, CLARITY の脳組織透過技術 ${ }^{4}$ をとと, 組織 の灌流固定からヒントをえて, 脳以外の組織の透明 化と 3 次元蛍光染色を可能にする技術を開発した。 透過試薬を血管や脳脊髄循環経路に灌流させること で迅速な透明化と全身臓器への適応を可能にしたの である。また, 染色用の抗体や洗浄液も全身臓器へ 灌流した。 ヒトのように結合組織成分が多いものへ の応用にも期待したい.

\section{2, 自律神経に注目}

肥満やインスリン抵抗性, 動脈硬化症の研究は慢 性炎症や自然免疫を軸として進められてきたが, 神 経系と免疫との関連から自律神経の作用に注目が集 まっている.

心理社会的ストレスは, 免疫系の活性化を介して 高血圧, 糖尿病といったメタボリック症候群, 動脈 硬化, 血栓症などの多くの疾患のリスク因子であ る。脳と免疫系の間のクロストークは「視床下部一 下垂体－副腎軸」を介するグルココルチコイド産生 
や交感神経系を介するカテコラミン分泌が知られて いる．Heidt $ら^{5)}$ はストレスが交感神経の活性化を 介して, 造血系前駆細胞の増殖を促し，疾患を促進 する炎症性白血球のレベル上昇をもたらすことを示 した、ストレス尺度を増加させる, 集中治療室のロー テーション勤務終了後には, 白血球数が増加してい た。さまざまな飼育上の慢性ストレス状態に置かれ たマウスでも白血球増加がおこり，それは骨髄内交 感神経のノルアドレナリン放出と骨髄ニッチ細胞の アドレナリン $\beta 3$ 受容体を介した作用によるもので あった。ささらに，アテローム性動脈硬化モデル動物 である ApoE 欠損マウスを慢性ストレスにさらすと， 炎症性白血球増多による動脈硬化巣の増悪を認め た。これらの結果から，骨髄による交感神経刺激が 心理的ストレスと心血管イベントを関連づけること が示唆された。ストレスの持続により骨髄幹細胞が 増殖，プラークの不安定化に繋がる可能性がある。

これに関連して，骨髄の交感神経刺激と脾臓を介 した動脈硬化性血栓症の病態の悪循環が報告されて いる ${ }^{6}$ ．急性心筋梗塞に伴う急性炎症反応が慢性炎症 病巣である動脈硬化病変を促進させるという仮説を, ApoE 欠損マウスを用いて検証したものである。著者 らは心筋壊死が交感神経系の刺激を介して造血幹細 胞の遊離を促し, 脾臓での単核球造血により動脈硬 化巣への炎症細胞浸潤が増加すると考察している。

また，代謝，血管新生，交感神経を関連づける論 文が発表された。褐色脂肪細胞はミトコンドリアが 多く，脱共役タンパク質の働きにより脂肪を分解し て熱を産生する。褐色脂肪組織は血管が豊富である が，肥満個体ではこれが減少して低酸素環境を呈 し，褐色脂肪はミトコンドリア機能不全，脂肪滴の 集積という脂肪の“白色化”と血管網の減少を認め た。この変化に，脂肪特異的な血管内皮細胞増殖因 子(VEGF)-Aの発現低下，低酸素によるアドレナ リン $\beta$ 受容体シグナル伝達機構の抑制やミトコン ドリア機能傷害などが関与していた。過栄養による 肥満は，褐色脂肪組織の血管形成障害による虚血や 交感神経系の活性化の抑制をもたらし，ミトコンド リア機能不全と脂肪組織の白色化をもたらすことが 示された7).

なお，神経免疫ガイダンス分子であるネトリン 1 が動脈硬化巣や肥満状態の脂肪組織内のマクロ
ファージの滞留を誘導(遊出を抑制) し，動脈硬化巣 の炎症の遷延化やインスリン抵抗性に繋がることが 報告された ${ }^{8,9)}$. 動脈硬化巣では低酸素環境 ${ }^{10)}$ が, 脂 肪組織では飽和脂肪酸のパルミチン酸9)がそれぞれ ネトリン 1 の誘導因子と考えられている.

神経を電気刺激してパーキンソン病，てんかんの 治療を行うインプラントの開発がすでに進行中であ る ${ }^{11)}$ 。また，コリン作動性抗炎症経路の自律神経, アセチルコリン産生 $\mathrm{T}$ 細胞，脾臓内マクロファー ジの応答に関する総説 ${ }^{12}$ は興味深い.

\section{3，血液凝固第 VIII 因子の起源が決着}

凝固第 VIII 因子 (FVIII) は主に肝臓で産生される が，産生細胞が血管内皮細胞なのか肝実質細胞なの かこれまで決着がついていなかった. Everettら ${ }^{13)}$ は, FVIII およびFVの分泌過程に必要な LMAN (lectin, mannose-binding protein) 1 という細胞内タン パク質のコンデイショナル KO マウスを作製して解 析した。一方, Fahs ら $^{14)}$ は, FVIII そのもののコン ディショナル KO マウスを作製した。 LMAN1 遺伝 子あるいは FVIII 遺伝子を肝実質細胞特異的に欠損 させても血中 FVIII レベルは影響を受けなかったが, 血管内皮細胞特異的に欠損させると，全身で欠損さ せたマウスと同等のレベルまで血中 FVIII レベルが 減少した。また腎臓の血管内皮細胞でも FVIII の発 現が確認され $\left.{ }^{13}\right)$ ，骨髄由来細胞の関与は否定され た ${ }^{14)}$. Sharani $ら^{15)}$ は，移植時に得られたヒト肝組織 から肝蔵類洞内皮細胞と肝細胞を分離し，類洞内皮 細胞区分の FVIII 活性が肝細胞区分と比較して 10 100 倍高く，ヒトにおいても類洞内皮細胞が FVIII の 産生細胞として有力であることを示した。多彩な内 皮細胞の機能の一つに FVIII 産生が加わった。

\section{4, 冠動脈 MRI による心血管イベント予測}

医療において未来を予測することは非常に難しい が，冠動脈の血栓性合併症のリスクを非侵襲的に予 測する所見が報告された。これまでに，冠動脈 CT 検査にて，冠動脈陽性リモデリングと低 CT 值の 2 つの所見をもつ症例は，それがない症例と比較して 冠動脈血栓症を有意に高い確率で発症することが示 されている。しかしながら, 被曝, 造影剂アレルギー や腎機能への影響の懸念から検査の反復には制限が 
ある。この点, 造影剤を用いない MRI 検査は腎負 荷，放射線被曝の問題がない. Noguri $5^{16)}$ は, 非造 影 $\mathrm{T} 1$ 強調画像で高輝度に描出される冠動脈プラー クの検出が心血管イベントの予測因子となることを 明らかにした。非造影 $\mathrm{T} 1$ 強調検査を受けた 568 人 を平均 4 年間以上経過観察し, プラークの輝度が周 囲心筋と比較して 1.4 倍以上高い症例で冠動脈イ ベントの発症割合が高いことを示し, その半数以上 が検査後 1 年以内に発症していた。また全症例を冠 動脈疾患の有無とプラークの輝度 (1.4のカットオフ 值)で 4 群に分けると, プラークの輝度が 1.4 以上 かつ冠動脈疾患の既往がある群は 3 年で $30 \%$ と最

|||||||||||||||||||||||||||||||||||||||||||||||||||||||||||||||||||||||||||||||||||||||||||||||||||||||||||

1) Kang JH, Super M, Yung CW, Cooper RM, Domansky K, Graveline AR, Mammoto T, Berthet JB, Tobin H, Cartwright MJ, Watters AL, Rottman M, Waterhouse A, Mammoto A, Gamini N, Rodas MJ, Kole A, Jiang A, Valentin TM, Diaz A, Takahashi K, Ingber DE: An extracorporeal blood-cleansing device for sepsis therapy. Nat Med 20: 1211-1216, 2014.

2) Susaki EA, Tainaka K, Perrin D, Kishino F, Tawara T, Watanabe TM, Yokoyama C, Onoe H, Eguchi M, Yamaguchi S, Abe T, Kiyonari H, Shimizu Y, Miyawaki A, Yokota H, Ueda HR: Whole-brain imaging with single-cell resolution using chemical cocktails and computational analysis. Cell 157: 726-739, 2014.

3) Yang B, Treweek JB, Kulkarni RP, Deverman BE, Chen CK, Lubeck E, Shah S, Cai L, Gradinaru V: Single-cell phenotyping within transparent intact tissue through whole-body clearing. Cell 158: 945-958, 2014.

4) Chung K, Wallace J, Kim SY, Kalyanasundaram S, Andalman AS, Davidson TJ, Mirzabekov JJ, Zalocusky KA, Mattis J, Denisin AK, Pak S, Bernstein H, Ramakrishnan C, Grosenick L, Gradinaru V, Deisseroth K: Structural and molecular interrogation of intact biological systems. Nature 497: 332-337, 2013.

5) Heidt T, Sager HB, Courties G, Dutta P, Iwamoto Y, Zaltsman A, von Zur Muhlen C, Bode C, Fricchione GL, Denninger J, Lin CP, Vinegoni C, Libby P, Swirski FK, Weissleder R, Nahrendorf M: Chronic variable stress activates hematopoietic stem cells. Nat Med 20: 754-758, 2014.

6) Dutta P, Courties G, Wei Y, Leuschner F, Gorbatov R, Robbins CS, Iwamoto Y, Thompson B, Carlson AL, Heidt T, Majmudar MD, Lasitschka F, Etzrodt M, Waterman P, Waring MT, Chicoine AT, van der Laan AM, Niessen HW, Piek JJ, Rubin BB, Butany J, Stone JR, Katus HA, Murphy SA, Morrow DA, Sabatine MS, Vinegoni C, Moskowitz MA, Pittet MJ, Libby P, Lin CP, Swirski FK, Weissleder R, Nahrendorf M: Myocardial infarction accelerates atherosclerosis. Nature 487: 325-329, 2012.

7) Shimizu I, Aprahamian T, Kikuchi R, Shimizu A, Papanicolaou KN, MacLauchlan S, Maruyama S, Walsh K: Vascular rarefaction mediates whitening of brown fat in obesity. J Clin Invest 124: 2099-2112, 2014.
も心血管イベントを発症しやすく, プラークの輝度 が 1.4 未満かつ冠動脈疾患の既往がない群では心血 管イベントをほとんど発症しなかった。プラークの 輝度が 1.4 以上のプラークの存在は, 心血管イベン トの既往群と同等の心血管イベントリスクであるこ とが明らかとなった，頸動脈プラークの報告による と $\mathrm{T} 1$ 強調画像における高輝度はプラーク内出血を 反映しているとされるが, 冠動脈での報告がないた め, 高輝度プラークと病理組織の比較に関する検討 が期待される。また，本検討をもとに，薬剤による 介入が冠動脈イベントを抑制するのかが今後の検討 課題である。
姑

8) van Gils JM, Derby MC, Fernandes LR, Ramkhelawon B, Ray TD, Rayner KJ, Parathath S, Distel E, Feig JL, AlvarezLeite JI, Rayner AJ, McDonald TO, O'Brien KD, Stuart LM, Fisher EA, Lacy-Hulbert A, Moore KJ: The neuroimmune guidance cue netrin-1 promotes atherosclerosis by inhibiting the emigration of macrophages from plaques. Nat Immunol 13: 136-143, 2012.

9) Ramkhelawon B, Hennessy EJ, Ménager M, Ray TD, Sheedy FJ, Hutchison S, Wanschel A, Oldebeken S, Geoffrion M, Spiro W, Miller G, McPherson R, Rayner KJ, Moore KJ: Netrin-1 promotes adipose tissue macrophage retention and insulin resistance in obesity. Nat Med 20: 377-384, 2014.

10) Ramkhelawon B, Yang Y, van Gils JM, Hewing B, Rayner KJ, Parathath S, Guo L, Oldebeken S, Feig JL, Fisher EA, Moore KJ: Hypoxia induces netrin-1 and Unc5b in atherosclerotic plaques: mechanism for macrophage retention and survival. Arterioscler Thromb Vasc Biol 33: 1180-1188, 2013.

11) Reardon S: Electroceuticals spark interest. Nature 511: 18, 2014.

12) Martelli D, McKinley MJ, McAllen RM: The cholinergic anti-inflammatory pathway: a critical review. Auton Neurosci 182: 65-69, 2014.

13) Everett LA, Cleuren AC, Khoriaty RN, Ginsburg D: Murine coagulation factor VIII is synthesized in endothelial cells. Blood 123: 3697-3705, 2014.

14) Fahs SA, Hille MT, Shi Q, Weiler H, Montgomery RR: A conditional knockout mouse model reveals endothelial cells as the principal and possibly exclusive source of plasma factor VIII. Blood 123: 3706-3713, 2014.

15) Shahani T, Covens K, Lavend'homme R, Jazouli N, Sokal E, Peerlinck K, Jacquemin M: Human liver sinusoidal endothelial cells but not hepatocytes contain factor VIII. J Thromb Haemost 12: 36-42, 2014.

16) Noguchi $T$, Kawasaki $T$, Tanaka $A$, Yasuda $S$, Goto $Y$, Ishihara M, Nishimura K, Miyamoto Y, Node K, Koga N: High-intensity signals in coronary plaques on noncontrast T1-weighted magnetic resonance imaging as a novel determinant of coronary events. J Am Coll Cardiol 63: 989-999, 2014. 